\title{
A comparison of strategies for working capital management of listed food companies from Northern Europe
}

\author{
Serhiy Zabolotnyy ${ }^{1}$ and Timo Sipiläinen ${ }^{2}$ \\ ${ }^{1}$ Department of Finance, Warsaw University of Life Sciences - SGGW, Poland \\ ${ }^{2}$ Department of Economics and Management, University of Helsinki, Finland \\ e-mail: serhiy_zabolotnyy@sggw.pl
}

\begin{abstract}
The research presents the application of fuzzy logic for synthetic evaluation of strategies for working capital management of twelve food companies from Northern Europe in 2005-2015. A set of financial ratios formed an aggregated indicator reflecting the complexity of relationships between the level and structure of current assets and liabilities of a firm. Based on the proposed indicator, four types of strategies for working capital management were identified and characterized in terms of risk and return preferences. Only a few companies from the sample demonstrated a direct orientation on liquidity or value within their strategies for working capital management. To retain flexibility in short-term financial management, most firms applied moderate policies for current assets and liabilities that helped them in maintaining liquidity and reducing the cost of financing. The integrity of the proposed method for the synthetic evaluation of working capital management makes it a convenient managerial tool suitable for use in firms operating in a turbulent business environment.
\end{abstract}

Key words: food industry, finance, liquidity, fuzzy logic

\section{Introduction}

Since working capital is one of the principal drivers of value in a company, its scarcity causes many adverse effects beginning with gaps in financing current operations and ending with insolvency in the long-term (Deloof 2003, Chatterjee 2012, Vural et al. 2012). In many cases, the imperfections in working capital management result in a decrease in the market value and a significant rise in the risk of liquidity, which commonly refers to the inability to pay current liabilities (Baños-Caballero et al. 2019). Therefore, managers balance the level of the working capital to mitigate the negative impact of a trade-off between risk and return (Apak et al. 2016, Huang and Mazouz 2018, Peng and Zhou 2019). The application of such an approach supports the continuity of business and provides a sufficient return on assets. It also requires a profound policy or strategy for working capital management that perfectly fits the specific goals of the company and its shareholders. Some types of these strategies focus on the value of a firm and increase the risk of liquidity, while others maximize solvency and consequently reduce the return on equity. Besides, vast empirical evidence confirms that various policies for working capital management influence both the value and liquidity of a firm (de Almeida and Eid 2014, Aktas et al. 2015, Wieczorek-Kosmala et al. 2016). However, the relationship between these categories is not straightforward and remains subject to many economic factors (Enqvist et al. 2014, Çelik et al. 2016, Pirttilä et al. 2019, Tsuruta 2019).

The popular method of exploring working capital refers to the application of traditional financial measures such as liquidity or turnover ratios (Kasiran et al. 2016, Dar and Dar 2017). The shortcoming of this approach lies in the inability to integrate fragmentary results of evaluation into the overall model of risk management and fit it in the managerial decision-making process (Trigueiros 1994). Hence, there is a need for complex research addressing the methodology of assessment of working capital management and liquidity risk on a firm-level. Regarding the existing research gap, the goal of the article is to identify variables influencing the working capital and present the method for the integrated evaluation of working capital management of a firm. The research unveils the complex indicator that comprises the impact of different financial factors on the working capital, and unambiguously defines the strategy for working capital management in a firm. The integrity of the proposed indicator makes it a convenient managerial tool suitable for use in entities operating in a turbulent business environment. 


\section{AGRICULTURAL AND FOOD SCIENCE}

\section{Material and methods}

The complexity and vagueness of the relationship between particular factors influencing working capital management determined the use of the fuzzy logic and synthetic evaluation method for estimation in the research. While the application of fuzzy logic is more common in studies of competitiveness or strength of entities on different levels of aggregation, there is limited research devoted to its use in the evaluation of corporate management practices on a firm-level in particular industries. The current research and proposed practical solutions aim to bridge the gap between theoretical assumptions and managerial patterns used for the evaluation of the financial management of food companies. The fuzzy logic approach allows the assessment of uncertain and multivariate information for the decision-making process (Taş and Gürsoy 2016, Bottani et al. 2017). A fuzzy function precisely ranks the values of particular variables according to the degree of their membership to a data set (Chen et al. 2014). For example, in the given interval [0;1], the full non-membership of a single observation corresponds to zero, and its full-membership refers to one. In the study, the information from a combination of financial variables $(x 1, x 2, x 3, x 4, x 5, x 6, x 7, x 8)$ was aggregated in the complex indicator $A$, whose values in the interval $[0 ; 100]$ unambiguously characterized strategies for working capital management of particular firms from the sample. Additionally, selected variables were divided into two sub-indicators, $A_{1}$ and $A_{2}$, that depicted the relationship between the level and structure of current assets $\left(A_{1}\right)$ and current liabilities $\left(A_{2}\right)$ as principal components of the process of working capital management (Table 1).

\begin{tabular}{llll}
\multicolumn{4}{l}{ Table 1. Indicators of working capital management strategy of a business entity } \\
\hline Variable & Construction & Sub-indicator & Impact \\
\hline$X_{1}$ & Current Assets/Total Assets & $A_{1}$ & Positive \\
$X_{2}$ & Inventory/Current Assets & $A_{1}$ & Negative \\
$X_{3}$ & Accounts receivable/Current Assets & $A_{1}$ & Negative \\
$X_{4}$ & Cash and Equivalents/Current Assets & $A_{1}$ & Positive \\
$X_{5}$ & Current Liabilities/Total Assets & $A_{2}$ & Negative \\
$X_{6}$ & Accounts Payable/Current Liabilities & $A_{2}$ & Positive \\
$X_{7}$ & Short-term Debt/Current Liabilities & $A_{2}$ & Negative \\
$X_{8}$ & Current Liabilities/Equity & $A_{2}$ & Negative \\
\hline
\end{tabular}

Source: authors' research.

Depending on the impact on the synthetic evaluation criterion $A$ in terms of risk and return, different rules for transformation of values of Individual variables were used. For variables with a negative impact on working capital, the transformation was as follows:

$$
\mu(X)=\left\{\begin{array}{c}
0 x=x_{\max } \\
\frac{x_{\max }-x}{x_{\max }-x_{\min }} \quad x_{\min }<x<x_{\max } \\
1 x=x_{\min }
\end{array}\right\},
$$

where $x_{\max }$ - the maximum value for a variable in the data set, and $x_{\min }$ - the corresponding minimum value.

Variables with a positive impact on working capital were transformed using the formula:

$$
\mu(X)=\left\{\begin{array}{c}
0 x=x_{\min } \\
\frac{x-x_{\min }}{x_{\max }-x_{\min }} \quad x_{\min }<x<x_{\max } \\
1 x=x_{\max }
\end{array}\right\},
$$

As a result, the evaluation matrix of transformed values for each object in the data was specified:

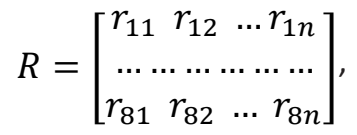




\section{AGRICULTURAL AND FOOD SCIENCE}

where $r_{i j}=\mu(X), i=1,2, \ldots, 8$ variables and $j=1,2, \ldots, n-$ objects.

The complexity of relationships between variables justified the use of equal weights for their aggregation:

$$
w=\frac{1}{n} \text { and } \sum_{i=1}^{8} w_{i}=1,
$$

where $n$ - number of factors in the complex indicator, $w_{i}$ - the weight of $i$ variable.

Finally, the complex indicator of the strategy for working capital management was constructed according to the following formula:

$$
A_{i}=100 *\left(a_{1}, a_{2} \ldots a_{n}\right) \times\left[\begin{array}{cccc}
r_{11} & r_{12} & \ldots & r_{1 n} \\
\ldots & \ldots & \ldots & \ldots \\
r_{81} & r_{82} & \ldots & r_{8 n}
\end{array}\right]=\left(b_{1}, b_{2} \ldots b_{n}\right)
$$

where:

$A_{i}$ - the complex indicator,

$\alpha_{n}$-the weight of $i$ factor,

$b_{1}, b_{2} \ldots b_{n}$-components of the indicator $A_{i}$.

According to theoretical assumption and transformation rules, the distribution of values of the complex indicator on the scale of $[0 ; 1]$ or equivalent $[0 ; 100]$ means that the maximum characterizes the strategy for working capital management with the lowest risk of liquidity. The minimum value of the complex indicator corresponds to the policy resulting in the highest risk of liquidity. Following the risk-return concept, strategies with a lower level of risk are referred to as conservative, and those with a higher level of risk are noted as aggressive (Fig. 1).

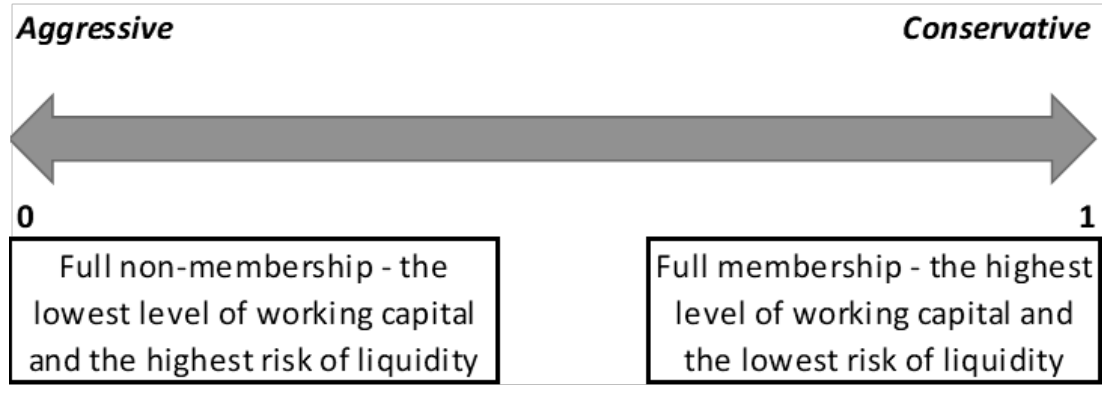

Fig. 1. A fuzzy logic approach to the strategy for working capital management

The conservative strategy for working capital management maintains the highest liquidity by maximizing the surplus of current assets over current liabilities. It also implies the excess of cash and the predominance of noninterest accounts payable in the structure of current assets and liabilities. Conversely, for aggressive strategy, a high liquidity risk relates to a drop in current assets, and an increase in short-term liabilities, particularly financial debt.

The relationship between the sub-indicators of current assets $\left(A_{1}\right)$ and current liabilities $\left(A_{2}\right)$ suggests four types of strategies for working capital management (Fig. 2).

Strategies A and C depict two opposite scenarios for working capital management in terms of risk of liquidity. In strategies $B$ and $D$, the overall moderate risk of liquidity derives from various combinations between current assets and liabilities. Theoretically, the classification of strategies for particular firms always relies on the distribution of transformed values in the fuzzy dataset and the choice of the reference point or a benchmark. However, from a practical point of view, different firm-level factors such as specificity of operations, organizational structure, or market position of a company, as well as external variables including industry, a stage of a business cycle or complexity of a supply chain, may influence the classification of strategies in a particular group of entities. Therefore, policies considered to be aggressive or moderate in one sample may turn conservative in another one in a particular period that would largely depend on numerous external and internal economic factors. In this context, it should be mentioned that the study presents the conceptual framework and a methodological approach to the definition and assessment of the working capital strategy on a firm-level. Virtually, depending on the selected criteria, the manager can easily adjust the combination of proposed variables or change the benchmark 


\section{AGRICULTURAL AND FOOD SCIENCE}

to fit the evaluation of business performance to the particular goal of the analysis. For example, the introduction of such "growth" factors as a change in revenue, level of profitability, investment rate, or market position of a company would probably help better understand the impact of the business environment on the relevant strategy. In our case, the inclusion of new business factors into the assessment of the working capital management of food companies from the research sample would require a broader study of the strength and direction of their potential impact that goes beyond the scope of the presented methodological approach.

\begin{tabular}{|c|c|}
\hline $\begin{array}{l}\text { A1-min B } \\
\text { A2-max } \\
\text { Value-oriented management of } \\
\text { current assets and liquidity- } \\
\text { oriented management of current } \\
\text { liabilities. } \\
\text { Moderate risk of liquidity- } \\
\text { Balanced Strategy (type I). }\end{array}$ & $\begin{array}{l}\text { A1-max A } \\
\text { A2-max } \\
\text { Liquidity-oriented management of } \\
\text { current assets and current } \\
\text { liabilities. } \\
\text { Low risk of liquidity-Conservative } \\
\text { Strategy. }\end{array}$ \\
\hline $\begin{array}{l}\text { A1-min } \quad \text { C } \\
\text { A2-min } \\
\text { Value-oriented management of } \\
\text { current assets and current } \\
\text { liabilities. } \\
\text { High risk of liquidity - Aggressive } \\
\text { Strategy. }\end{array}$ & $\begin{array}{l}\text { A1-max D } \\
\text { A2-min } \\
\text { Liquidity-oriented management of } \\
\text { current assets and value-oriented } \\
\text { management of current liabilities. } \\
\text { Moderate risk of liquidity- } \\
\text { Balanced Strategy (type II). }\end{array}$ \\
\hline
\end{tabular}

\section{A1 - Current Assets (Investing)}

Fig. 2. Types of strategies for working capital management

The study covered the sample of twelve joint-stock food companies from Northern Europe: six from Norway, four from Finland, and two from Sweden. It included five companies engaged in the production of seafood, two firms from the meat sector, three suppliers of a variety of food consumer goods, one company producing oil products, and one supplier of flour and cereal products. All food companies from the sample were listed in stockexchanges of Northern Europe and publicly announced their consolidated financial statements in 2005-2015. The Bloomberg (www.bloomberg.com) and Thomson Reuters (www.thomsonreuters.com) databases were used to access the public financial data of the sample companies. The research sample was quite specific due to the size, structure, and strength of particular companies as they probably represent the most technologically advanced and insightful vertically integrated business models functioning in the global food industry. In 2005-2015 the average and the median for revenue of food companies in the sample were $1779 \mathrm{mln}$ USD and $1184 \mathrm{mln}$ USD, while their average and the median for assets amounted to $2210 \mathrm{mln}$ USD and $1154 \mathrm{mln}$ USD accordingly. The results of the research are not extrapolated on a larger population to avoid the fuzziness problem in the applied method (Sanches and Trillas 2012).

\section{Results and discussion}

Food companies from Northern Europe demonstrated moderate fluctuations in liquidity ratios in 2005-2015 (Fig. 3). The ratio of net working capital to total assets is scaled on the left vertical axis, and the liquidity ratios are attributed to the right vertical axis. The average value of the current ratio reached 2.5, and working capital made $24.3 \%$ of total assets that proved a high ability of firms to cover short-term liabilities. The minimum value of the current ratio amounted to 2.0 in 2005, and the maximum to 2.8 in 2010, while the quick ratio and cash ratio fell by 0.1 in the same period, indicating the rising level of inventory in sample food companies. However, the growth of the quick ratio from 1.0 in 2011 to 1.2 in 2014 and the cash ratio from 0.4 to 0.6 demonstrated a subsequent improvement of the liquidity of current assets.

Furthermore, a positive relationship between the liquidity and working capital determined the rise of the share of working capital in total assets by $7.3 \mathrm{pp}$. in 2010 compared to 2005 . Consequently, the drop in the share of working capital in assets from $24.5 \%$ in 2013 to $22.6 \%$ in 2015 corresponded to a plunge in the current ratio from 2.7 to 2.4 . 


\section{AGRICULTURAL AND FOOD SCIENCE}

S. Zabolotnyy \& T. Sipiläinen (2020) 29: 239-249

Considering fluctuations of liquidity ratios, we would assume the minor impact of the financial crisis of 2008-2009 on the working capital of sample companies from the food industry in Northern Europe. However, the rising current ratio, along with a smaller change in quick ratio, gave support to the assumption on the deteriorating demand for the products of sample companies in 2008-2010 as their inventory levels became relatively higher. In subsequent years, as a possible response to deficiencies of liquid assets, these companies tended to maintain higher cash balances that also positively influenced their financial sustainability in the aftermath of the crisis. Therefore, the impact of the financial crisis of 2008-2009 on food companies could be twofold: in a short-run, the fall of demand on their products automatically increased current liquidity due to the rise of inventory, while in the longrun managers stimulated sales revenues by extending credit terms and gradually built up higher levels of cash improving the quick and cash ratios.

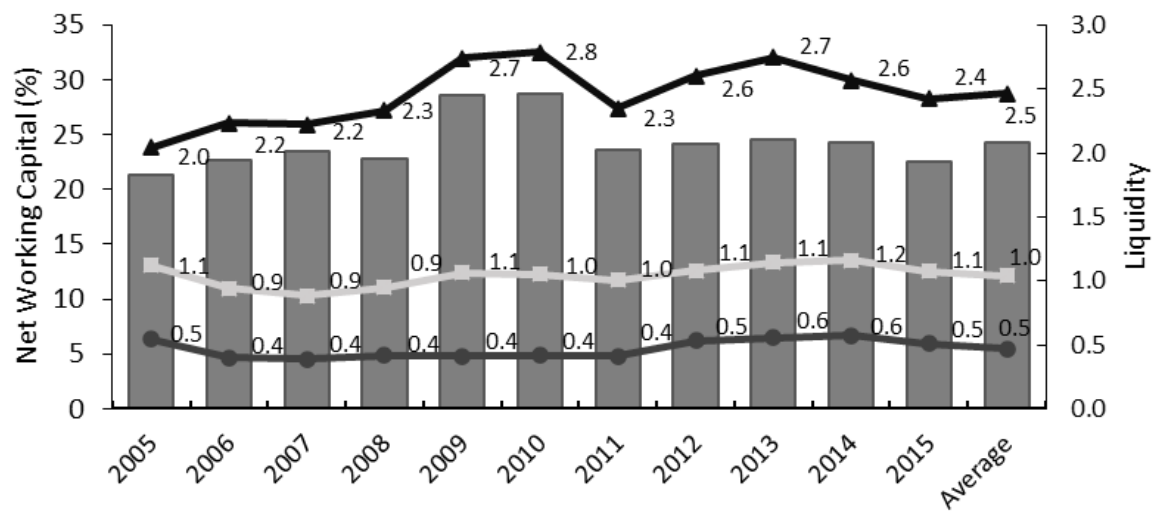

$\square$ Net Working Capital/Total Assets (\%) -Current Ratio - - - Quick Ratio - Cash Ratio

Fig. 3. Annual means of liquidity of food companies from Northern Europe

The sub-indicator of current assets $\left(A_{1}\right)$ characterized the strategy for current assets' management in food companies from Northern Europe (Table 2). The fluctuations of values of sub-indicators derived from changes in combinations of partial financial variables that formed these sub-indicators and could have adverse effects on the level of working capital in particular companies.

Table 2. The sub-indicator of current assets (A1) of food companies from Northern Europe

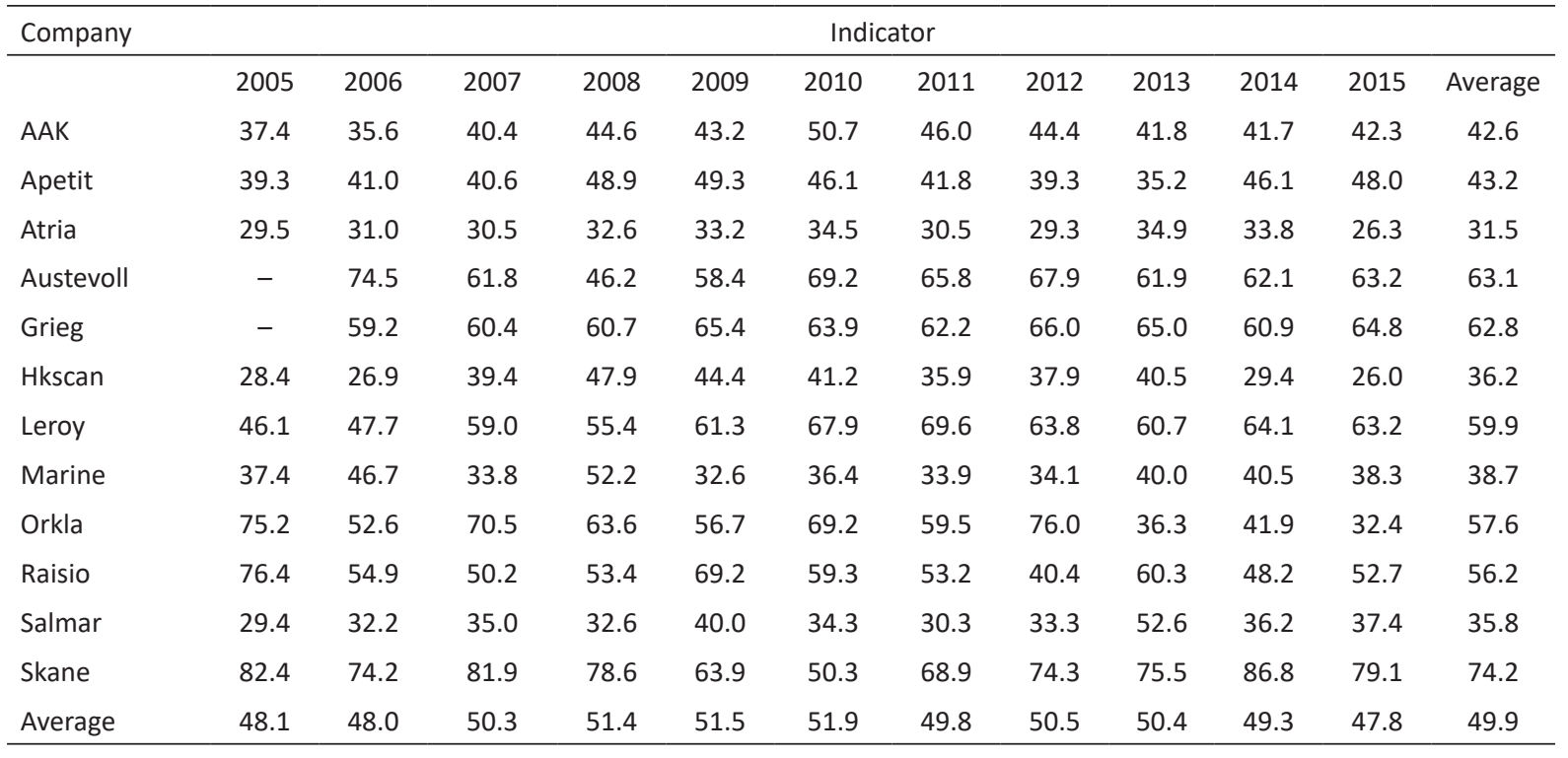

This indicator rose from 48.1 to 51.9 in 2005-2010 and then dropped to 47.8 in 2015, while its average value reached 49.9. There was a straightforward relationship between liquidity and the value of the $A_{1}$ ratio, as it reflected changes in working capital levels in sample companies. Generally, the high value of $A_{1}$ conveyed liquidity orientation of a firm that derived from a large amount of current assets, particularly cash surplus, and a proportionally smaller portion of inventory and accounts receivable. The low level of $A_{1}$ corresponded to a value 


\section{AGRICULTURAL AND FOOD SCIENCE}

S. Zabolotnyy \& T. Sipiläinen (2020) 29: 239-249

orientation, implying the deficit of current assets and the predominance of inconvertible inventory. The highest average values of the sub-indicator of current assets were noted in such companies as Skane (74.2), Grieg (62.8), and Austevoll (63.1), while the lowest values in such entities as Atria (31.5), Salmar (35.8) and Hkscan (36.2).

The distribution of financial ratios that formed the sub-indicator $A_{1}$ shed light on relationships among particular components of strategies for working capital management in food companies from Northern Europe (Fig. 4). The left vertical axis presents the values of sub-indicator $A_{1}$, and the right vertical axis reflects the distribution of the set of financial variables composing this complex indicator. It should be mentioned that the distribution of average values of indicators in the companies was dependent both on combinations of partial financial variables forming sub-indicators in particular years and the fluctuations of values of sub-indicators in the presented timeline.

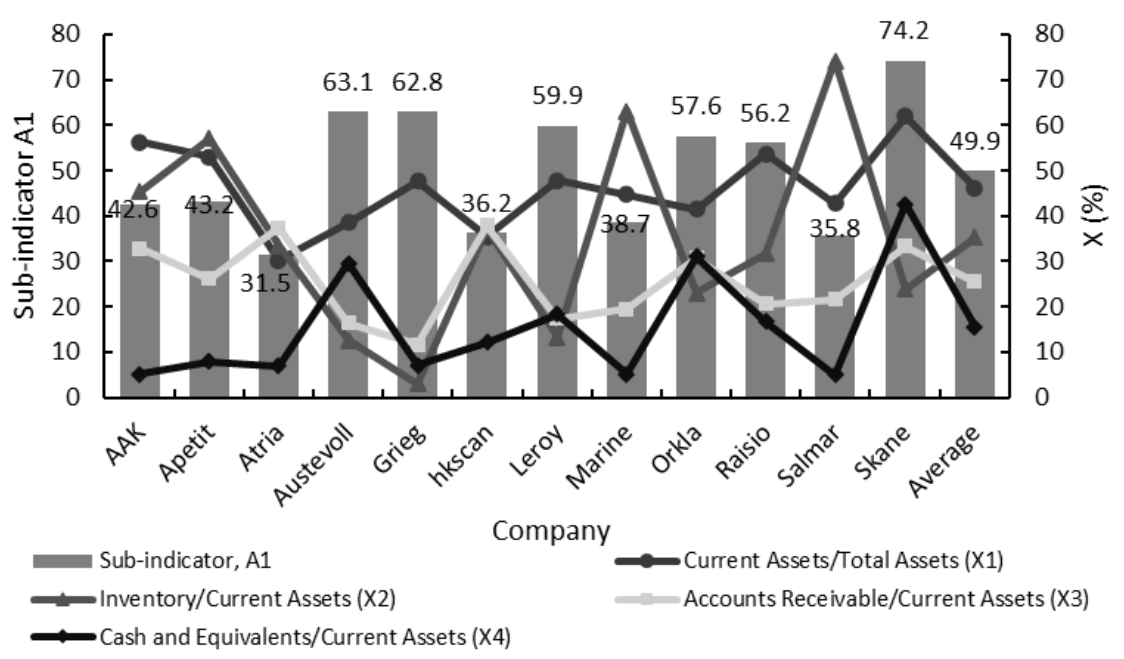

Fig. 4. The average values of components of the sub-indicator of current assets (A1) of food companies from Northern Europe in 2005-2015

None of the companies with high values of the sub-indicator $A_{1}$ demonstrated a clear orientation on liquidity within the strategy for current assets' management. For example, Grieg maintained a large share of current assets in total assets (47.6\%), but only an insignificant part of them was in the form of cash (7.1\% of current assets). Conversely, Austevoll showed a comparatively small share of current assets in total assets (38.5\%), while cash was a significant source of liquidity in this company (29.6\% of current assets). This approach helped companies to balance risk and return and decrease the cost of liquidity in short-term management. Skane was the only company that maximized the value of the sub-indicator $A_{1}$ by increasing both the amount of current assets $(62 \%$ of total assets) and cash (42.5\% of current assets). In the group of companies with low sub-indicators $A_{1}$, the strategies for working capital management were vague. For example, Salmar had a significant share of current assets (42.8\% of total assets), and low cash reserves ( $5 \%$ of current assets) that additionally implied the decrease of liquidity due to a large inventory ( $74.2 \%$ of current assets) and accounts receivable (15.7\% of current assets). Other companies with low sub-indicators $A_{1}$, such as Atria and Hkscan, demonstrated relatively low levels of current assets (respectively $30.2 \%$ and $30.5 \%$ of total assets) and cash (7.0\% and $12.1 \%$ of current assets) in $2005-2015$.

The sub-indicator $A_{2}$ described the policy for current liabilities' management in food companies from Northern Europe (Table 3). The high value of $A_{2}$ referred to a low level of current liabilities with a predominance of noninterest accounts payable. The gradual growth of the sub-indicator from 58.0 in 2006 to 68.3 in 2014 implied an overall increase in working capital and a drop in interest expense on short-term debt that subsequently indicated a lowering liquidity risk in sample entities.

Companies with high values of $A_{2}$ such as Skane (85.0), Marine (74.1), and Raisio (72.0) demonstrated a relatively small share of current liabilities compared to total assets $(12.2 \%-20.3 \%)$ and equity capital $(14.9 \%-32.8 \%)$ (Fig. 5). In Figure 5, the left vertical axis demonstrates the values of sub-indicator $A_{2}$, and the right vertical axis shows the distribution of the set of financial variables composing this complex indicator. At the same time, these entities extensively used accounts payable (41.5\%-45.5\% of current liabilities) and reduced the short-term debt ( $0 \%$ to $20.1 \%$ of current liabilities). 
Table 3. The sub-indicator of current liabilities (A2) of food companies from Northern Europe

\begin{tabular}{lcccccccccccc}
\hline Company & & \multicolumn{10}{c}{ Indicator } \\
\hline \multirow{3}{*}{ AAK } & 2005 & 2006 & 2007 & 2008 & 2009 & 2010 & 2011 & 2012 & 2013 & 2014 & 2015 & Average \\
Apetit & 65.4 & 46.3 & 60.6 & 49.0 & 67.4 & 61.3 & 70.8 & 72.9 & 74.2 & 75.8 & 70.7 & 65.0 \\
Atria & 46.7 & 37.6 & 52.9 & 66.8 & 83.4 & 80.9 & 88.6 & 53.1 & 70.1 & 69.8 & 45.0 & 63.2 \\
Austevoll & 45.1 & 63.5 & 48.4 & 50.6 & 52.4 & 51.7 & 53.0 & 53.0 & 49.7 & 60.9 & 62.5 & 53.7 \\
Grieg & - & 57.3 & 42.5 & 52.6 & 57.8 & 61.0 & 57.3 & 58.8 & 64.1 & 64.0 & 56.9 & 57.2 \\
Hkscan & - & 42.8 & 44.8 & 0.0 & 41.0 & 58.2 & 38.1 & 41.9 & 50.7 & 46.9 & 62.5 & 42.7 \\
Leroy & 41.8 & 38.2 & 55.0 & 55.9 & 54.5 & 45.8 & 41.0 & 37.8 & 41.5 & 63.7 & 63.4 & 49.0 \\
Marine & 71.1 & 61.7 & 62.4 & 54.7 & 61.8 & 68.4 & 62.0 & 62.6 & 69.6 & 74.5 & 56.5 & 64.1 \\
Orkla & 65.7 & 67.2 & 67.3 & 59.0 & 84.8 & 79.6 & 83.5 & 77.5 & 75.0 & 76.0 & 79.0 & 74.1 \\
Raisio & 56.2 & 66.3 & 69.9 & 83.5 & 75.7 & 74.4 & 71.7 & 55.0 & 63.1 & 74.3 & 84.1 & 70.4 \\
Salmar & 71.4 & 68.0 & 78.7 & 79.4 & 73.4 & 77.6 & 63.3 & 70.4 & 72.0 & 66.2 & 71.9 & 72.0 \\
Skane & 57.7 & 61.4 & 68.5 & 61.5 & 71.2 & 82.5 & 58.5 & 64.5 & 71.8 & 67.8 & 74.7 & 67.3 \\
Average & 82.7 & 85.1 & 81.8 & 90.7 & 89.1 & 96.2 & 75.6 & 84.0 & 81.8 & 80.1 & 87.6 & 85.0
\end{tabular}

Conversely, companies with low sub-indicators $A_{2}$ such as Grieg (42.7), Hkscan (49.0), and Atria (53.7) presented a comparatively high level of current liabilities that covered $26.4 \%-32.8 \%$ of total assets and $69.1 \%-88.0 \%$ of equity capital. Additionally, these firms hold fewer accounts payable $(28.0 \%-37.0 \%$ of current assets), and more short-term debt (35.3\%-62.1\% of current assets). It should be added that comparatively higher volatility of ratios of the strategy for current liabilities' might arise out of seasonality and ambition of managers for matching the structure of the liabilities to fluctuations in current assets.

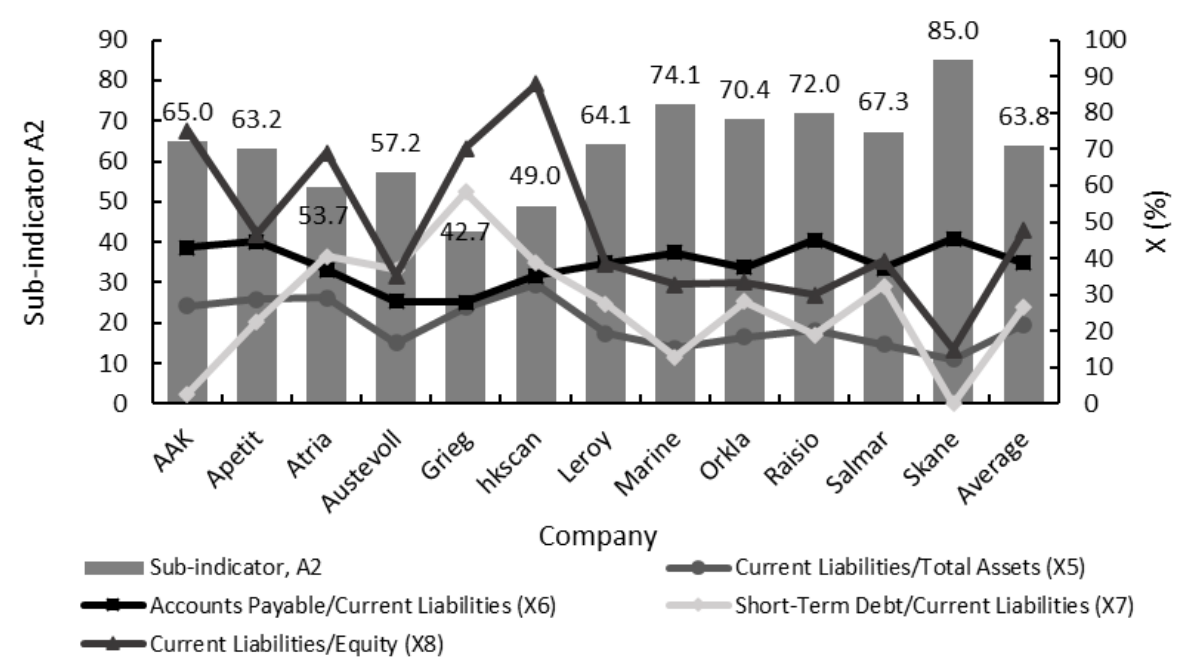

Fig. 5. The average values of components of the sub-indicator of current liabilities (A2) of food companies from Northern Europe in 2005-2015

The complex indicator $A$ being the average value of $A_{1}$ and $A_{2}$ demonstrated the overall strategy for working capital management in companies from Northern Europe (Table 4).

High indicators gave evidence of rising orientation on liquidity in some companies, including Skane (79.6), Raisio (64.1), and Orkla (64.0). Preference for value maximization supported by comparatively lower indicators was noticed in such entities as Atria (42.6), Hkscan (42.6), and Salmar (51.5). There was only one company in the sample (Skane) with a straightforward conservative approach to working capital management (Fig. 6). This firm showed a direct orientation on liquidity and reached an extremely high current ratio (5.6), quick ratio (3.7), and cash ratio (2.4). Conversely, Atria and Hkscan, entities with a clear focus on value, demonstrated low current ratios (1.0 and 1.1 respectively), quick ratio (0.5 and 0.6$)$, and cash ratio (0.1 and 0.1$)$. 
Table 4. The complex indicator (A) of strategies for working capital management of food companies from Northern Europe

\begin{tabular}{|c|c|c|c|c|c|c|c|c|c|c|c|c|}
\hline \multirow[t]{2}{*}{ Company } & \multicolumn{12}{|c|}{ Indicator } \\
\hline & 2005 & 2006 & 2007 & 2008 & 2009 & 2010 & 2011 & 2012 & 2013 & 2014 & 2015 & Average \\
\hline AAK & 51.4 & 41.0 & 50.5 & 46.8 & 55.3 & 56.0 & 58.4 & 58.7 & 58.0 & 58.8 & 56.5 & 53.8 \\
\hline Apetit & 43.0 & 39.3 & 46.8 & 57.9 & 66.4 & 63.5 & 65.2 & 46.2 & 52.6 & 58.0 & 46.5 & 53.2 \\
\hline Atria & 37.3 & 47.2 & 39.5 & 41.6 & 42.8 & 43.1 & 41.7 & 41.1 & 42.3 & 47.4 & 44.4 & 42.6 \\
\hline Austevoll & - & 65.9 & 52.1 & 49.4 & 58.1 & 65.1 & 61.6 & 63.4 & 63.0 & 63.0 & 60.0 & 60.2 \\
\hline Grieg & - & 51.0 & 52.6 & 30.4 & 53.2 & 61.1 & 50.1 & 53.9 & 57.9 & 53.9 & 63.7 & 52.8 \\
\hline Hkscan & 35.1 & 32.5 & 47.2 & 51.9 & 49.4 & 43.5 & 38.5 & 37.8 & 41.0 & 46.6 & 44.7 & 42.6 \\
\hline Leroy & 58.6 & 54.7 & 60.7 & 55.1 & 61.5 & 68.1 & 65.8 & 63.2 & 65.2 & 69.3 & 59.8 & 62.0 \\
\hline Marine & 51.5 & 56.9 & 50.6 & 55.6 & 58.7 & 58.0 & 58.7 & 55.8 & 57.5 & 58.2 & 58.6 & 56.4 \\
\hline Orkla & 65.7 & 59.5 & 70.2 & 73.5 & 66.2 & 71.8 & 65.6 & 65.5 & 49.7 & 58.1 & 58.2 & 64.0 \\
\hline Raisio & 73.9 & 61.5 & 64.4 & 66.4 & 71.3 & 68.5 & 58.3 & 55.4 & 66.1 & 57.2 & 62.3 & 64.1 \\
\hline Salmar & 43.5 & 46.8 & 51.7 & 47.1 & 55.6 & 58.4 & 44.4 & 48.9 & 62.2 & 52.0 & 56.1 & 51.5 \\
\hline Skane & 82.6 & 79.6 & 81.8 & 84.6 & 76.5 & 73.2 & 72.2 & 79.2 & 78.6 & 83.4 & 83.3 & 79.6 \\
\hline Average & 54.3 & 53.0 & 55.7 & 55.0 & 59.6 & 60.9 & 56.7 & 55.8 & 57.8 & 58.8 & 57.9 & 56.9 \\
\hline
\end{tabular}

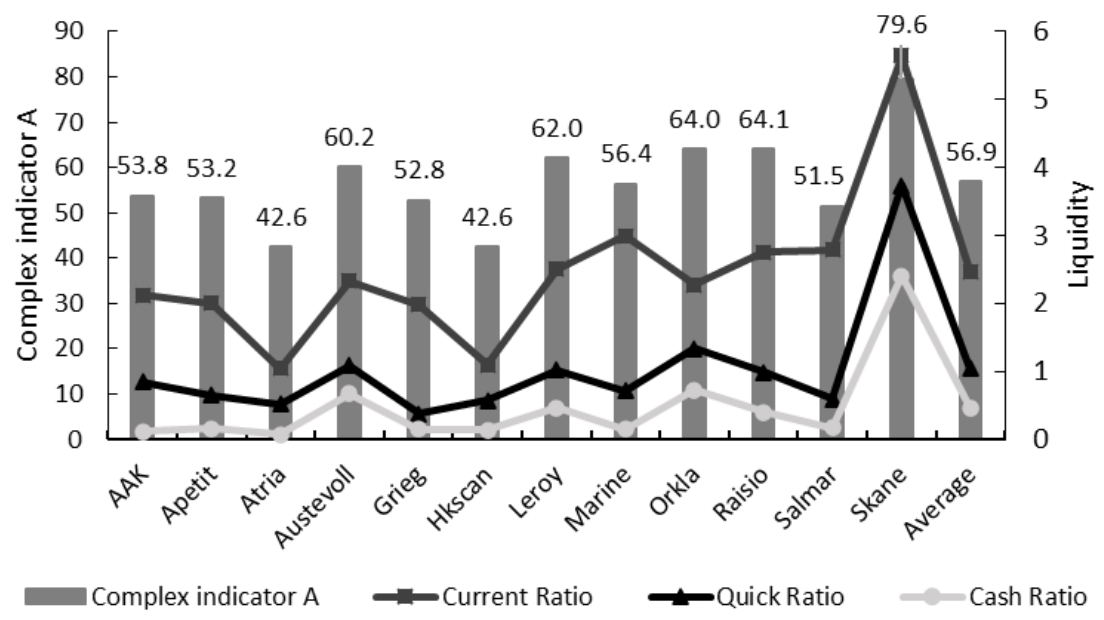

Fig. 6. The average values of complex indicator of strategies for working capital management (A) versus liquidity ratios of food companies from Northern Europe in 2005-2015

However, many firms, including Marine and Salmar, achieved average values of the complex indicator $A$ that derived from various combinations of current assets and liabilities. A large gap between the current and quick ratios in these entities might arise from ineffective inventory management, along with a drop in revenue. In other companies from the group with moderate strategies, such as Norwegian firms Austevoll and Leroy, the decrease of current ratios and increase of quick and cash ratios indicated the growing efficiency of working capital management.

The analysis of complex indicators and financial ratios proved the existence of a variety of unique strategies for working capital among food companies from Northern Europe. The use of statistical measures helped to evaluate the dispersion and trends in shaping the strategies for working capital management (Table 5).

The population standard deviation ( $\sigma$ ) and coefficient of variation (c) of complex indicators showed that strategies for current assets appeared to be more dispersed on average $(\sigma=13.2$ and $c=0.26)$ than strategies for current liabilities $(\sigma=11.1$ and $c=0.17)$. It supported the argument that in some food companies, probably with extreme orientation on value or liquidity, liabilities might not be entirely matched against the timing of cash flows from operating activities that formed the level and structure of current assets. If not controlled by managers, the 


\section{AGRICULTURAL AND FOOD SCIENCE}

S. Zabolotnyy \& T. Sipiläinen (2020) 29: 239-249

deterioration of the relationship between current assets and current liabilities during a year might decrease the efficiency of working capital management, including the growth of idle cash and the rise of the cost of short-term financing. However, the combination of strategies for current assets and liabilities suppressed the dispersion of the overall strategy for working capital management in food companies as the standard deviation for $A$ dropped to 9.7. Furthermore, considering the distribution of values of the standard deviation over time, we hypothesized a probability of an inverse relation between $A_{1}$ and $A_{2}$ that would mean companies tended to use moderate strategies for working capital management to balance the risk-return trade-off in short-term financial management. Besides, we noticed that the overall strategy for working capital management became less dispersed in the sample over time as the distribution of values of the coefficient of variation decreased from the range of $0.20-0.28$ in 2005-2008 to 0.15-0.20 in 2009-2015.

Table 5. Dispersion of strategies for working capital management of food companies from Northern Europe

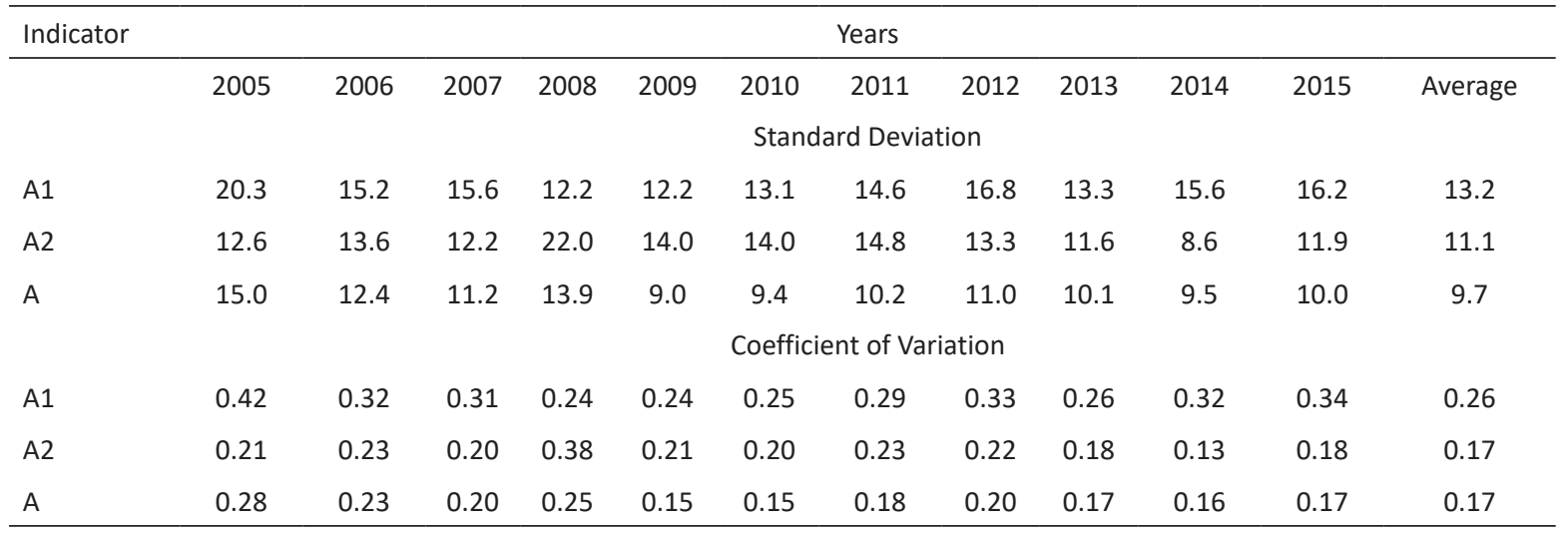

The graphical presentation of the relationship between the sub-indicator of current assets $A_{1}$ and sub-indicator of current liabilities $A_{2}$ helps to identify four scenarios of overall strategies for working capital management of food companies from Northern Europe (Fig. 7). The distribution of indicators supported the argument on the extremely conservative approach to working capital management in the case of the Swedish company Skane that maintained a high level of current and liquid assets and a low level of current liabilities with a predominance of accounts payable. In other companies from group A, including Raisio, Orkla, and Leroy, the difference between current assets and liabilities was not so large as the values of indicators approached the benchmark and indicated lesser orientation on liquidity. Companies with aggressive strategies for working capital management such as Apetit, Atria, and Hkscan (group C) had a low level of current assets with/or a predominance of inventory and accounts receivable along with a large share of current liabilities. The combination mentioned above significantly reduced liquidity and implied a rising probability of financial distress in these companies.

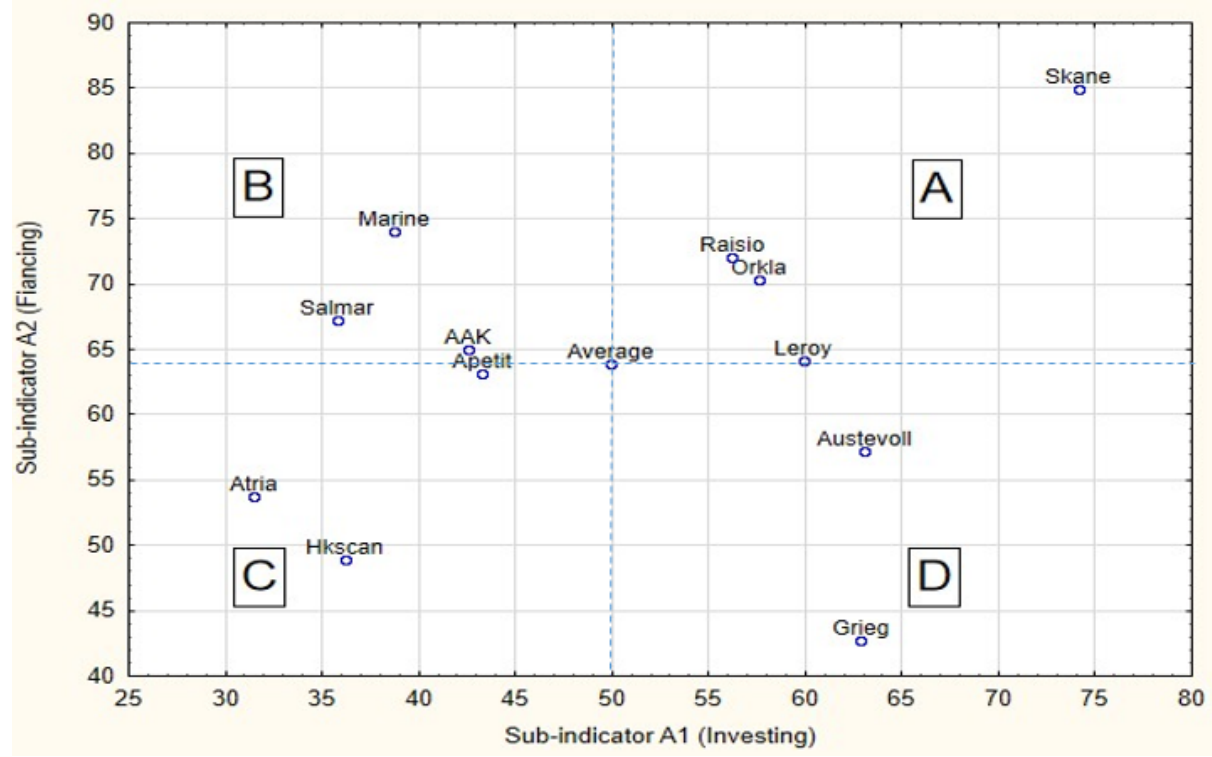

Fig. 7. Strategies for working capital management of food companies from Northern Europe 


\section{AGRICULTURAL AND FOOD SCIENCE}

S. Zabolotnyy \& T. Sipiläinen (2020) 29: 239-249

The moderate strategy for working capital management implied the balance between risk and return and demonstrated two variants. Firms using the first variant (group B), including AAK, Salmar, and Marine, compensated the deficit of cash by the reduction of accounts payable or short-term debt that consequently supported the level of working capital and positively influenced the liquidity. Conversely, companies from group D, such as Austevoll and Grieg, covered a large share of short-term debt by increased balances of current assets. The inclusion of a notable portion of short-term items might result in complicating the liquidity management and increase the risk of distress in these firms. However, an attempt to match the level of current assets and current liabilities gave evidence of the flexibility of strategies for working capital management in food companies from Northern Europe.

\section{Conclusions}

The depth and weight of the problem of working capital management require a detailed study of the relationship between the level and structure of current assets and current liabilities that have a significant impact on the liquidity and value of the firm. The research focused on the application of fuzzy logic and a synthetic evaluation method to assess the working capital management in food companies from Northern Europe. The use of the complex indicator as an evaluation criterion helped to identify four types of strategies for working capital management and characterize them in terms of risk and return preferences. Growth in the value of the complex indicator illustrated diminishing liquidity risk and return and referred to a conservative strategy for working capital management. Companies applying this strategy increased the amount of current and most liquid assets and cut current liabilities to maximize liquidity. However, such behavior could lead to adverse effects deriving from the drop in cash flow and the rise in the cost of financing. Conversely, aggressive strategy implied low complex indicators that pointed to a value orientation in the short-term financial management of a firm. Companies with this type of strategy expanded current liabilities and limited liquid assets to maximize the return for shareholders. However, despite short-term benefits, aggressive strategy could lead to a significant rise in financial risk and result in the loss of a firm's value in the long-term. Considering these arguments, only a few companies from the sample demonstrated a clear orientation on liquidity or value within their strategies for working capital management. It was noticed that managers preferred to use moderate strategies for working capital that implied diverse relationships among components of short-term assets and liabilities. For example, standard practices in the companies from the sample included matching the level and structure of current assets with liabilities by maximizing cash balances to offset the negative impact of increasing short-term debt. Another method for working capital management was decreasing the inventory and current liabilities to reduce the cost of operations and increase the liquidity of assets. As a result, this helped to enforce a balance between liquidity and value and improved the risk-return relationship in the firms. Therefore, the application of various strategies for working capital management mitigated the fluctuations of liquidity and decreased the financial risk in food companies from Northern Europe in 2005-2015.

In the concluding remark, it should be mentioned that the limitations of the current study justify some critical comments for future research. The problem of causality remains a challenge in empirical studies on business economics and corporate finance in particular. Understanding whether the strategy is forced by the environment (for example, a stage of a business cycle) or arises solely from managerial decisions, requires a bunch of detailed information on a business entity. From a researcher's point of view, this critical issue can be attempted to solve by the application of additional instruments, such as surveys with a set of specific questions addressed to inside stakeholders. However, empirical testing suggests that managerial response tends to be subjective due to wellknown behavioral factors and conflicts of interest among various groups of stakeholders. In this case, the application of control variables, such as size, growth rate, market strength, or a geographical region of a business entity, might support the findings of the empirical research. In the current study, the size and specificity of the sample of food companies make it challenging to statistically control for relationships between working capital and selected other factors. In this context, it should be mentioned that the foremost intention of the research was to indicate the complexity of the problem and give managers the instrument to assess and modify their strategies considering different combinations of factors, and different evaluation criteria/benchmarks. Furthermore, defending the empirical findings, it should be admitted that financial ratios used in the current approach could be partially explained by some exogenous factors not directly included in the analysis. For example, higher inventory on the balance sheet could indicate shortages on the demand side, extended receivables and cash balance would signal the increasing business activity, while a sharp rise in liabilities probably demonstrate the financial turbulences. The authors will put further efforts to overcome the mentioned problem in future research by enlarging the sample both in size and geographic representation and dividing it into subsections, as well as conducting case studies on a firm-level that would help to control the specificity of business models and their environment. 


\section{AGRICULTURAL AND FOOD SCIENCE}

\section{Acknowledgments}

We thank the anonymous reviewers of the paper for their valuable comments. Any errors in the text are the responsibility of the authors. The research was financed from internal sources of the affiliated institutions.

\section{References}

Aktas, N., Croci, E. \& Petmezas, D. 2015. Is Working Capital Management Value-Enhancing? Evidence from Firm Performance and Investments. Journal of Corporate Finance 30: 98-113. https://doi.org/10.1016/j.jcorpfin.2014.12.008

de Almeida, J.R. \& Eid, W. 2014. Access to Finance, Working Capital Management and Company Value: Evidences from Brazilian Companies Listed on BM\&FBOVESPA. Journal of Business Research 67: 924-934. https://doi.org/10.1016/j.jbusres.2013.07.012

Apak, S., Açıkgöz, A.F., Erbay, E.R. \& Tuncer, G. 2016. Cash vs. Net Working Capital as Strategic Tools for the Long-Term Relation between Bank Credits and Liquidity: Inequalities in Turkey. Procedia - Social and Behavioral Sciences 235 (November): 648-655. https://doi.org/10.1016/j.sbspro.2016.11.046

Baños-Caballero, S., García-Teruel, P.J. \& Martínez-Solano, P. 2019. Net Operating Working Capital and Firm Value: A CrossCountry Analysis. BRQ Business Research Quarterly. Available online 4 April 2019. In Press, Corrected Proof. https://doi.org/10.1016/j.brq.2019.03.003

Bottani, E., Gentilotti, M.C. \& Rinaldi, M. 2017. A Fuzzy Logic-Based Tool for the Assessment of Corporate Sustainability: A Case Study in the Food Machinery Industry. Sustainability 9: 583. https://doi.org/10.3390/su9040583

Chatterjee, S. 2012. The Impact of Working Capital on the Profitability: Evidence from the Indian Firms. SSRN Scholarly Paper ID 2125228. Rochester, NY: Social Science Research Network. 74 p. https://doi.org/10.2139/ssrn.2125228

Chen, Q., Sipiläinen, T. \& Sumelius, J. 2014. Assessment of Agri-Environmental Externalities at Regional Levels in Finland. Sustainability 6: 3171-3191. https://doi.org/10.3390/su6063171

Çelik, R., Bilen, B. \& Bilen, Ö. 2016. The Impacts of Changes in Macro-Economic Data on Net Working Capital: The Case of Turkey's Industrial Sector. Procedia Economics and Finance 38: 122-134. https://doi.org/10.1016/S2212-5671(16)30184-8

Dar, S.Q. \& Dar, A.A. 2017. The Working Capital and Its Ratios: A Qualitative Study. International Journal of Statistics and Actuarial Science 1: 24-30.

Deloof, M. 2003. Does Working Capital Management Affect Profitability of Belgian Firms? Journal of Business Finance \& Accounting 30: 573-588. https://doi.org/10.1111/1468-5957.00008

Enqvist, J., Graham, M. \& Nikkinen, J. 2014. The Impact of Working Capital Management on Firm Profitability in Different Business Cycles: Evidence from Finland. Research in International Business and Finance 32 (August): 36-49. https://doi.org/10.1016/j.ribaf.2014.03.005

Huang, W. \& Mazouz, K. 2018. Excess Cash, Trading Continuity, and Liquidity Risk. Journal of Corporate Finance 48 (February): 275-291. https://doi.org/10.1016/j.jcorpfin.2017.11.005

Kasiran, F.W., Mohamad, N.A. \& Chin, O. 2016. Working Capital Management Efficiency: A Study on the Small Medium Enterprise in Malaysia. Procedia Economics and Finance 35: 297-303. https://doi.org/10.1016/S2212-5671(16)00037-X

Peng, J. \& Zhou, Z. 2019. Working Capital Optimization in a Supply Chain Perspective. European Journal of Operational Research 277: 846-56. https://doi.org/10.1016/j.ejor.2019.03.022

Pirttilä, M., Virolainen, V.M., Lind, L. \& Kärri, T. 2019. Working Capital Management in the Russian Automotive Industry Supply Chain. International Journal of Production Economics: Available online 30 August 2019. In Press, Corrected Proof. https://doi.org/10.1016/j.ijpe.2019.08.009

Sánchez, D. \& Trillas, E. 2012 Measures of Fuzziness under Different Uses of Fuzzy Sets. In: Advances in Computational Intelligence, Catania, Italy. p. 25-34. https://doi.org/10.1007/978-3-642-31715-6_4

Taş, O. \& Gürsoy, Ö.Z. 2016. A Fuzzy Logic Based Technical Indicator for BIST 30 Index and Islamic Index. Procedia Economics and Finance 38: 203-212. https://doi.org/10.1016/S2212-5671(16)30191-5

Triqueiros, D. 1994. Incorporating Complementary Ratios in the Analysis of Financial Statements. Accounting, Management and Information Technologies 4: 149-162. https://doi.org/10.1016/0959-8022(94)90002-7

Tsuruta, D. 2019. Working Capital Management during the Global Financial Crisis: Evidence from Japan. Japan and the World Economy 49 (March): 206-219. https://doi.org/10.1016/j.japwor.2019.01.002

Vural, G., Sökmen, A.G. \& Çetenak, E.H. 2012. Affects of Working Capital Management on Firm's Performance: Evidence from Turkey 2: 488-495.

Wieczorek-Kosmala, M., Doś, A., Błach, J. \& Gorczyńska, M. 2016. Working Capital Management and Liquidity Reserves: The Context of Risk Retention. Journal of Economics \& Management 23: 5-20.

www.bloomberg.com

www.thomsonreuters.com 